\title{
The effects of a combined implant of trenbolone acetate and oestradiol-17 $\beta$ on protein and energy metabolism in growing beef steers
}

\author{
By G. E. LOBLEY, ALEXMARY CONNELL, G. S. MOLLISON, \\ A. BREWER, C. I. HARRIS AND VIVIEN BUCHAN
}

Rowett Research Institute, Bucksburn, Aberdeen AB2 9SB

\author{
AND H. GALBRAITH
}

Department of Agriculture, University of Aberdeen, 581 King Street, Aberdeen AB9 $1 U D$

(Received 8 November 1984 - Accepted 10 June 1985)

1. The effects on growth performance, energy and nitrogen retention, and leucine metabolism of a subcutaneous combined implant of $140 \mathrm{mg}$ trenbolone acetate (TBA) $+20 \mathrm{mg}$ oestradiol-17 $\beta$ (OE) have been examined in Hereford $\times$ Friesian beef steers $(280-520 \mathrm{~kg})$. Comparisons were made both with the same animals before implantation and with untreated control animals maintained under similar physiological and nutritional conditions.

2. Over a 10 week period the implanted steers showed an improvement in rate of live-weight gain (LWG) of $0.5-0.6$ with an even greater proportional increase in $\mathrm{N}$ retention compared with control animals. Total energy retention was unaffected and thus the ratio, protein energy:total energy gain was 0.43 for implanted steers compared with 0.26 for untreated animals.

3. Estimates of protein synthesis and protein oxidation were obtained from the specific radioactivities of blood free-leucine and exhaled carbon dioxide during continuous infusions of $\left[1-{ }^{14} \mathrm{C}\right]$ leucine. Whole-body protein synthesis, based on metabolic size, and amino acid fractional oxidation remained similar for control steers throughout the experiment. Steroid-treated steers showed a slight decline in synthesis which was significant $(P<0.05)$ at week +5 post-implant while amino acid oxidation was significantly lower at weeks $+2(P<0.01)$ and $+5(P<0.05)$ compared with control animals. The ratio, protein deposition: protein synthesis was 0.05 for control animals but $0.08-0.10$ for steroid-treated animals after implantation.

4. There was a slight decrease in urinary $N^{\top}$-methylhistidine elimination after implantation which suggested that muscle protein degradation may be reduced although the estimated decrease was insufficient to account for the total improvement in growth rate and $\mathrm{N}$ retention.

5. The results suggest that for both control and treated steers, less than 0.5 of total urine $\mathrm{N}$ elimination was derived directly from tissue catabolism of protein and amino acids.

6. The combined action of the exogenous steroids in the promotion of protein gain, primarily through a decrease in total protein degradation with little alteration of total energy retention, is compared with present understanding of the role of the endogenous sex hormones.

The various secretions of the testis influence the metabolism and behaviour of the male animal in a characteristic manner. Compared with castrates the entire males usually have faster rates of live-weight gain (LWG), exhibit greater appetite and at maturity achieve a greater body-weight and produce a leaner carcass. It is still the majority practice, however, in the UK to castrate male cattle and sheep destined for meat production and to offset the commercial disadvantages that result from gonadectomy by the use of exogenous growth promoters.

One such compound, the steroid trenbolone acetate (TBA; androst-1,9(10),11-trien3-one,-17 acetate) is widely used, either alone or in combination with an oestrogen, especially in cattle where improvements in LWG and nitrogen retention and carcass quality have all been reported (see Galbraith \& Topps, 1981). It is unclear what determines the alterations in fat and protein deposition and whether the mode of action is similar to that of the endogenous gonadal secretions. TBA has been described as a testosterone substitute 
(Heitzman, 1980) but recent studies have suggested that its effects on metabolic rate (Huisman et al. 1980) and on muscle protein metabolism (Vernon \& Buttery, 1978a) may be different from those expected of testosterone. To examine this situation further, steers were implanted with a combination of TBA and oestradiol-17 $\beta(\mathrm{OE})$ and under controlled nutritional conditions the effects on heat production and leucine metabolism were studied. Preliminary reports of this work have already appeared (Lobley et al. 1982, 1983a; Harris et al. 1984).

\section{METHODS}

\section{Animals and diets}

Hereford $\times$ Friesian steers were purchased locally (9-12 months old; $180-230 \mathrm{~kg}$ live weight). Expt $\mathrm{A}$ involved eight animals; six of these were sired by the same bull and all were born within 1 month of each other. A further two animals were purchased 18 months later. Expt B involved six animals all obtained from a single herd. For at least 4 months before each experiment the animals were adjusted to a ration of ruminant diet AA6 (ABRO, Edinburgh; 17.5 MJ gross energy (GE)/kg dry matter (DM), $25.2 \mathrm{~g} \mathrm{~N} / \mathrm{kg} \mathrm{DM}$ ) supplied from continuous-belt-type feeders. The amounts of ration offered were based on the metabolizable energy (ME) estimated to support a $L W G$ of $0.8 \mathrm{~kg} / \mathrm{d}$ and the ration quantities were adjusted every 3 weeks according to the formula:

$$
\text { ME offered }(M J)=(0 \cdot 153 \times \text { animal weight }(\mathrm{kg}))+16 \cdot 1 \text {. }
$$

The metabolizability of the AA6 diet was assumed initially to be 0.55 (Wainman et al. 1975) but during Expt A it became obvious that batches of diet showed marked variation in metabolizability and that the average value was less than $0 \cdot 55$. Accordingly, for the period following the second implant in Expt A and for Expt B, metabolizability was assumed to be 0.50 .

\section{Experimental design}

Animals were trained to spend up to $6 \mathrm{~d}$ in one of two automated confinement respiration chambers (Blaxter et al. 1972) while wearing harnesses to permit collection of faeces by a chute (Brockway, 1979) and urine by suction into $4 \mathrm{M}$-sulphuric acid. In both experiments each animal occupied a chamber at intervals of 3 weeks. In Expt $A$ the period of confinement was usually $6 \mathrm{~d}$ and in Expt B $4 \mathrm{~d}$. The confinement period started 1 week after adjustment of the ration quantity.

In both experiments animals were assessed on a variety of criteria including stature, conformation and growth performance. On the basis of these criteria steers were matched in pairs as far as possible and one of each pair allocated to either the treatment or control group. The aim of this selection procedure was to reduce, as far as possible, bias between the control and treatment groups. This was considered especially important in a procedure which involved limited numbers of animals and where inter-animal differences may be large. Because of the repetitive nature of the experimental design the same two animals, which corresponded in fact to the original matchings, would always be measured together. Despite this the intention was always to analyse the results on a group and not a pair basis: the statistical consequences of this are described later.

Expt A commenced when the animals reached $290 \mathrm{~kg}$. They then underwent two periods of chamber measurement (i.e. weeks -4 and -1 ) before one of each pair was implanted subcutaneously at the base of the ear with eight pellets which contained in total $140 \mathrm{mg}$ TBA and $20 \mathrm{mg} O E$ (Revalor; Hoechst, Hounslow, Middlesex). Control animals were sham implanted. The animals were subsequently examined at weeks $+2,+5,+8$ and +11 after 
implantation. The first three treated steers in the trial then received a further implant of $140 \mathrm{mg}$ TBA and $20 \mathrm{mg} \mathrm{OE}$ at week +13 and were then studied at weeks $+14,+17,+20$ and +23 . The measurements were made on control animals as before and these were then continued beyond week +23 until such time as they reached the weight attained by the 'pair'-treated animal at week +23 .

In Expt B, treated animals were given only a single implant of the steroid preparation, at the same dose as in Expt $\mathrm{A}$. Measurements were made at weeks $-8,-5,-2,+1,+4,+7$ and +10 with respect to time of implanatation; control animals were again allowed to continue until they reached the weight of the equivalent 'pair' animal at week +10 .

\section{Experimental procedures}

Balance trials. Total energy and $\mathrm{N}$ balances were determined on each steer during the period of confinement in the respiration chamber.

Heat production was calculated from the total gaseous exchange over individual $24 \mathrm{~h}$ periods using the formula of Brouwer (1965). Samples of the daily urine collection were also taken for determination of $N^{\top}$-methylhistidine content (Harris \& Milne, 1981).

Metabolic measurements using radiotracers (Expt $A$ only). All radiochemicals were purchased from Amersham International plc, Amersham, Bucks.

Leucine metabolism. For measurement of leucine kinetics each animal was prepared with venous catheters immediately before each period of chamber confinement. Two polyvinyl catheters $(2.0 \mathrm{~mm}$ o.d., $1.4 \mathrm{~mm}$ i.d., Portex, Hythe, Kent) were inserted through 10-gauge syringe needles into one external jugular vein. Placement of the tip of one catheter in the right ventricle (infusion catheter) and the tip of the other $50 \mathrm{~mm}$ cranial to the heart (anterior vena cava; sample catheter) was aided by use of a blood pressure monitor. At least $48 \mathrm{~h}$ later during chamber confinement the animals were continuously infused for 8-10 h with $\mathrm{L}-\left[1-{ }^{14} \mathrm{C}\right]$ leucine (in sterile saline $(9 \mathrm{~g}$ sodium chloride/l), no carrier leucine added; $10 \mu \mathrm{Ci} / \mathrm{h} ; 80 \mathrm{ml} / \mathrm{h}$ ). Blood samples $(50 \mathrm{ml})$ were obtained during the last $4 \mathrm{~h}$ of the infusion, during the short periods when the chamber was ventilated with outside air (sampling interval 45-60 min; see Blaxter et al. 1972). The proportion of the $\left[{ }^{14} \mathrm{C}\right]$ leucine which was oxidized to ${ }^{14} \mathrm{CO}_{2}$ was determined at the end of each of four consecutive closed periods (duration $37-52 \mathrm{~min})$. Approximately 0.016 of the total chamber gas $\left(16 \mathrm{~m}^{3}\right)$ was withdrawn into butyl rubber tubes. This gas was then passed at a rate of 4 litres/min through 0.6 litres $0.7 \mathrm{M}$-sodium hydroxide in gas wash-bottles with size 0 sintaglass filters to trap ${ }^{14} \mathrm{CO}_{2}$. The carbonate was then precipitated by addition of a slight excess (approximately $0 \cdot 1$ ) of $1 \mathrm{M}$-barium chloride. Precipitated barium carbonate was collected by filtration, washed with 1 litre water, and dried at $105^{\circ}$ for $16 \mathrm{~h}$. A blank procedure was performed to assess residual carbonate in the $0.7 \mathrm{M}-\mathrm{NaOH}$ and to correct for any barium hydroxide formed. The blank correction was normally $0.02-0.05$ that of the total collection. Accurately weighed amounts $(2 \mathrm{~g})$ of $\mathrm{BaCO}_{3}$ powder were assayed for radioactivity using a Packard 306 Oxidiser (Lobley et al. 1985 ) and the specific radioactivity of the original ${ }^{14} \mathrm{CO}_{2}$ calculated.

Outflow rates of digesta. The fractional turnover of solid and liquid phases of digesta were estimated from the rates of appearance of ${ }^{103} \mathrm{Ru}$-phenanthroline and ${ }^{51} \mathrm{Cr}$-EDTA in the faeces. Each animal was given, at 12.00 hours on day 1 of chamber confinement, approximately $200 \mathrm{~g}$ AA6 pellets impregnated with a total of $5 \mathrm{ml}$ of a mixture of $30 \mu \mathrm{Ci}$ ${ }^{103} \mathrm{Ru}$-phenanthroline (prepared as described by Tan et al. 1971) and $150 \mu \mathrm{Ci}{ }^{51} \mathrm{Cr}$-EDTA. Grab samples of faeces were then obtained at known times over the next $5 \mathrm{~d}$. Triplicate samples of faeces were weighed $(3 \mathrm{~g})$ into polycarbonate tubes and the amounts of gamma-emission from the ${ }^{103} \mathrm{Ru}$ and ${ }^{51} \mathrm{Cr}$ determined. The tubes and contents were then freeze-dried, re-weighed, and the amounts of water and DM in each sample calculated. All ${ }^{103} \mathrm{Ru}$ radioactivity was assumed to be associated with the $\mathrm{DM}$ and all ${ }^{51} \mathrm{Cr}$ radioactivity 
with the liquid fraction and specific radioactivities were expressed per $\mathrm{g}$ respectively; best-fit curves for a first order process were then fitted and the rate constants for solid and liquid digesta estimated (Grovum \& Williams, 1973).

Steroid concentrations in plasma. On each occasion that the first six steers were in the chamber a sample of plasma was obtained at 14.00 hours on the day of infusion and the concentrations of TBA (see Donaldson et al. 1981) and OE (Varley et al. 1981) determined by radioimmunoassay.

Chemical analysis. Determinations of the energy and $\mathrm{N}$ contents of feed and excreta were by approved Association of Official Agricultural Chemists (1980) methods based on bomb calorimetry and Kjeldahl analysis. Free leucine was isolated from the blood and the specific radioactivity (SR) determined as described by Lobley et al. (1980).

Calculations. Leucine kinetics were calculated as follows:

$$
\text { irreversible loss rate }(\text { ILR } ; \mathrm{mmol} / \mathrm{h})=\frac{\text { infusion rate }(\mu \mathrm{Ci} / \mathrm{h})}{\text { SR blood free-leucine }(\mu \mathrm{Ci} / \mathrm{mmol})},
$$

fractional oxidation rate $(\mathrm{FOR})=\frac{\mathrm{SR}{ }^{14} \mathrm{CO}_{2}(\mu \mathrm{Ci} / \mathrm{mmol}) \times \mathrm{CO}_{2} \text { produced }(\mathrm{mmol} / \mathrm{h})}{\text { infusion rate }(\mu \mathrm{Ci} / \mathrm{h})}$

leucine oxidized $(\mathrm{LO} ; \mathrm{mmol} / \mathrm{h})=$ FOR $\times$ ILR,

leucine for protein synthesis $\left(\mathrm{ILR}_{\mathrm{syn}} ; \mathrm{mmol} / \mathrm{h}\right)=(1-\mathrm{FOR}) \times \mathrm{ILR}$.

Leucine metabolism $(\mathrm{mmol} / \mathrm{h}) \times 8.24$ was assumed to give the equivalent rate as $\mathrm{g}$ protein-N/d (from Lobley et al. 1980). Precise measurement of leucine metabolism would require first, for amino acid oxidation, a knowledge of the SR of blood 2-oxo-4methylpentanoate and second, for protein synthesis, isolation of the leucyl- $t$-RNA complexes or nascent polypeptides. The latter techniques are beyond the scope of studies such as these while for the former, preliminary observations demonstrated that unacceptable quantities of blood would need to be withdrawn in order to obtain adequate amounts of the oxo-acid. It was assumed that for comparative purposes the relation between the SR of blood free-leucine and the respective precursors for oxidation and synthesis remained unchanged during the period of experiment or as a result of treatment. All results derived from blood SR values are therefore minimum estimates.

\section{Statistical procedures}

The pre-implant values were subjected to analysis of variance in which the animal pairings were ignored even though the observed variation between pairs was often higher than that within pairs. Post-implant values were handled either by analysis of covariance on mean pre-implant values where such covariate relations apparently existed (Tables 3 and 4) or by the same method as for pre-implant values where they did not (Tables 1, 2 and 5). The analysis of the results in this fashion was planned from the outset of the experiment because of the recognized lack of resources. The purpose of the pairing procedure was to ensure that differences in response of individual animals due to factors such as stature, conformation, etc. were not confounded with treatment effects and would be efficiently accounted within observations during the post-implant period by covariance, where necessary, on pre-implant values. The effect of this approach is to increase the df for estimation of error compared witis that obtained from the standard analysis of paired comparisons (which incidentally in this case would have yielded only $2 \mathrm{df}$ ). The error estimate obtained in the approach used may, however, be positively biased in situations where the co-variance on pre-implant values does not explain all of the variability between-pairs as compared with that within-pairs. This was observed to occur in some instances and leads to conservative statistical tests, but 
Table 1. The effect of a combined implant of $140 \mathrm{mg}$ trenbolone acetate $(T B A)+20 \mathrm{mg}$ oestradiol-17 $\beta(O E)$ on growth performance of steers

(Mean values with their pooled standard errors of differences (SED).

Expt A: controls $n 3$, treated $n$ 4; Expt B: controls $n$, treated $n$ 3)

\begin{tabular}{|c|c|c|c|c|c|c|c|}
\hline \multirow[b]{3}{*}{ Period (weeks) } & & \multicolumn{3}{|c|}{ Expt $A$} & \multicolumn{3}{|c|}{ Expt B } \\
\hline & & \multirow{2}{*}{$\begin{array}{l}\text { Controls } \\
\text { Mean }\end{array}$} & \multicolumn{2}{|c|}{$\mathrm{TBA}+\mathrm{OE}$} & \multirow{2}{*}{$\begin{array}{l}\text { Controls } \\
\text { Mean }\end{array}$} & \multicolumn{2}{|c|}{$\mathrm{TBA}+\mathrm{OE}$} \\
\hline & & & Mean & SED $\dagger$ & & Mean & SED \\
\hline Pre-implant, -10 to 0 & $\begin{array}{l}\text { Initial wt (kg) } \\
\text { LWG (kg/week) } \\
\text { Intake (kg/week) }\end{array}$ & $\begin{array}{r}286 \\
4 \cdot 8 \\
53 \cdot 3\end{array}$ & $\begin{array}{r}297 \\
4.9 \\
54.4\end{array}$ & $\begin{array}{l}14 \\
1 \cdot 1 \\
2 \cdot 4\end{array}$ & $\begin{array}{r}305 \\
6 \cdot 9 \\
58 \cdot 1\end{array}$ & $\begin{array}{c}296 \\
7 \cdot 0 \\
57 \cdot 2\end{array}$ & $\begin{array}{l}12 \\
0 \cdot 6 \\
2 \cdot 2\end{array}$ \\
\hline Post-implant, 0 to +10 & $\begin{array}{l}\text { LWG }(\mathrm{kg} / \text { week }) \\
\text { Intake }(\mathrm{kg} / \text { week })\end{array}$ & $\begin{array}{r}4 \cdot 8 \\
60 \cdot 3\end{array}$ & $\begin{array}{l}8 \cdot 1^{* * * *} \\
63 \cdot 9^{-1}\end{array}$ & $\begin{array}{l}0 \cdot 4 \\
3 \cdot 0\end{array}$ & $\begin{array}{r}7 \cdot 3 \\
65 \cdot 0\end{array}$ & $\begin{array}{l}10 \cdot 9 * * \\
65 \cdot 5\end{array}$ & $\begin{array}{l}0 \cdot 7 \\
2 \cdot 2\end{array}$ \\
\hline Post-implant, 13-23 & $\begin{array}{l}\text { LWG }(\mathrm{kg} / \text { week }) \\
\text { Intake (kg/week) }\end{array}$ & $\begin{array}{r}6 \cdot 6 \\
68 \cdot 1\end{array}$ & $\begin{array}{r}7 \cdot 0 \\
72 \cdot 8\end{array}$ & $\begin{array}{l}0.8 \ddagger \\
1.5\end{array}$ & & & \\
\hline
\end{tabular}

LWG, live-weight gain.

The difference was statistically significant: ${ }^{*} P<0.05,{ }^{*} P<0.01,{ }^{* * *} P<0.001$.

$+5 \mathrm{df}$.

$\ddagger 4$ df.

this was invariably outweighed by the gain in efficiency due to recovery of df for error estimation. Values for live weight (Table 2) have not been subjected to covariance analysis which allows the pattern of adjustments made in other variables, which are expressed per unit metabolic weight $\left(\mathrm{kg}\right.$ live weight $\left.{ }^{0 \cdot 75}\right)$, to be determined.

\section{RESULTS}

\section{Animal performance}

In Expt A, one untreated animal consistently refused feed during the periods of chamber confinement and was withdrawn from the experiment. In both experiments the rates of LWG during the 10 weeks before implantation were similar for both control and treated steers (Table 1) although overall growth performance was superior in Expt B where the ration allocation was increased because of the lower than expected metabolizability of the diet (see p. 682). Sham implantation had little effect on the LWG of the steers whereas the implanted animals increased their rates of gain by at least 0.50 (Expt A $P<0.001$, Expt B $P<0.01$; see Table 1). During the trial period the treated steers received slightly more food than the untreated animals simply because of their faster growth rate and greater weight when rations were readjusted at three-weekly intervals. The increase in LWG of the treated animals compared with the controls exceeded the quantities of extra feed offered. It took the control group steers 16 weeks to achieve the live weights of the treated animals at 10 weeks post-implantation by which time the control group had consumed 0.60 more feed.

The rate of release of steroids from the pellets, as assessed by the concentrations of TBA and $\mathrm{OE}$ in the plasma, varied between animals (Fig. 1). In one steer no plasma TBA was detectable at $56 \mathrm{~d}$ and its $\mathrm{OE}$ concentration was lower than that for the other two animals after this time. The steer with the lowest maximal concentration but the highest concentration sustained at the 11 th week also had the best improvement overall in growth performance.

Some differences were observed for the metabolizability of the AA6 diet; these differences 

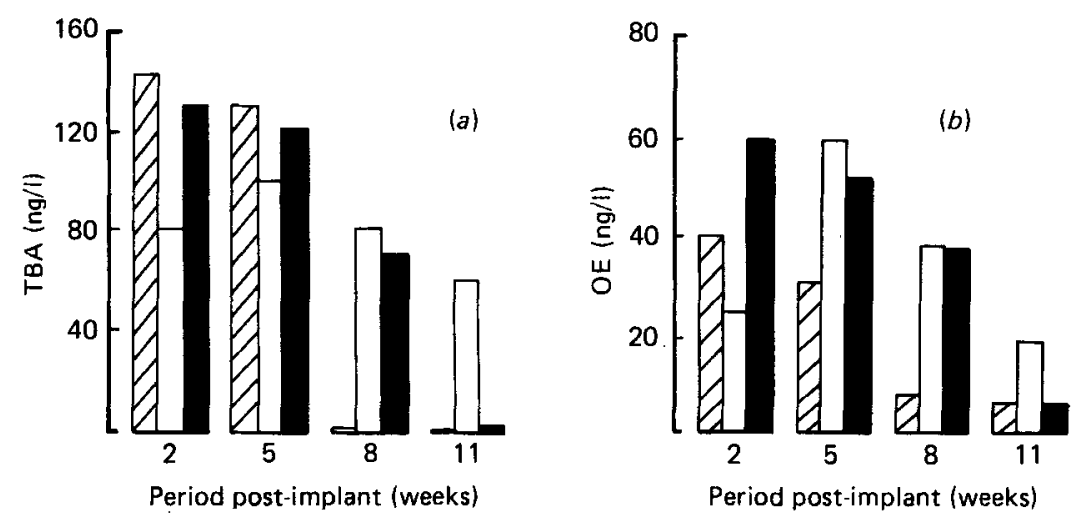

Fig. 1. Expt A. Increases in plasma concentration of $(a)$ trenbolone acetate (TBA) and $(b)$ oestradiol-17 $\beta$ (OE) for three treated animals (圈, $\square, \square$ ). The means of blank assays and control animal assays have been subtracted from the presented values (these amounted to $108 \mathrm{ng} / \mathrm{l}$ for the TBA determinations and $2 \mathrm{ng} / 1$ for the OE determinations).

existed both within and between batches. Similar variation was also found for the AA6 diet with sheep on feed evaluation trials (Wainman et al. 1984). In consequence it was necessary to make digestive comparisons between a pair of steers within a particular period of measurement.

There were no significant changes in either the digestibility or metabolizability of the feed as a result of treatment (results not shown), neither were there any significant effects of treatment on the outflow rates for the solid and liquid phase radioactive markers as assessed by analysis of the faecal decay curves. There were consistent differences between animals for the outflow rate of liquid. Mean half lives $(n 25)$ for solid and liquid components of digesta were $18.6(\mathrm{SD} 1.5) \mathrm{h}$ and 7.1 (SD 1.4 ) $\mathrm{h}$ respectively.

\section{Energy and $N$ retention}

Heat production increased during the course of each experiment in proportion to higher body-weight and dietary input (from Table 2) although there was considerable inter-animal variation. There was no evidence that implantation had any effect on heat production when expressed per unit metabolic body-weight (Table 2). Fluctuations between periods especially in Expt A were attributable mainly to differences in the metabolizability of the ration.

In both experiments the animals which received the implant showed an immediate improvement in $\mathrm{N}$ retention which at maximum, weeks +1 to +7 , was double that for control steers. This improvement, which was stronger in Expt B than in Expt A (Table 2), became less pronounced for weeks +8 to +11 . The proportional increase in $\mathrm{N}$ retention exceeded that in LWG. Comparison of the $\mathrm{N}$ and energy balance values showed that in untreated steers, protein energy $(\mathrm{N}$ retention $(\mathrm{g}) \times 6.25 \times 23.5)$ represented 0.26 of total energy retention whereas, following implantation, this was increased significantly $(P<0.02)$ to $0 \cdot 43$.

\section{Leucine metabolism}

Leucine ILR increased slightly for all animals during the experiment and, indeed, was higher for the treated compared with untreated steers when determined at 11 weeks after implantation (from Tables 2 and 3). This was presumably due to the greater weight and thus higher intake of the treated animals; comparison of the two groups at different times but at similar weight showed no difference in leucine ILR (analysis not shown). Variation 
Table 2. Live weight $(L W)$, heat production $(H P)$ and nitrogen retention at chamber measurements for control steers and those treated with $140 \mathrm{mg}$ trenbolone acetate $(T B A)+20 m g$ oestradiol-17 $\beta(O E)$

(Mean values with their pooled standard errors of differences (SED).

Expt A: controls $n$ 3, treated $n$ 4; Expt B: controls $n$ 3, treated $n$ 3)

\begin{tabular}{|c|c|c|c|c|c|c|c|c|c|}
\hline \multirow{2}{*}{$\begin{array}{c}\text { Treatment } \\
\text { period } \\
\text { (weeks) }\end{array}$} & \multicolumn{3}{|c|}{ LW (kg) } & \multicolumn{3}{|c|}{$\mathrm{HP}\left(\mathrm{kJ} / \mathrm{kg} \mathrm{LW^{0 \cdot 75 } )}\right.$} & \multicolumn{3}{|c|}{$N$ retention $(g / d)$} \\
\hline & Controls & $\mathrm{TBA}+\mathrm{OE}$ & SED $\dagger$ & Controls & $\mathrm{TBA}+\mathrm{OE}$ & SED $\dagger$ & Controls & $\mathrm{TBA}+\mathrm{OE}$ & SED $\dagger$ \\
\hline \multicolumn{10}{|c|}{ Expt A } \\
\hline-4 & 318 & 322 & 9 & 608 & 617 & 23 & $19 \cdot 5$ & $21 \cdot 0$ & $2 \cdot 6$ \\
\hline-1 & 335 & 337 & 14 & 643 & $592^{*}$ & 21 & $19 \cdot 9$ & $19 \cdot 2$ & 6.6 \\
\hline+2 & 345 & 365 & 17 & 650 & 604 & 32 & 17.6 & $41 \cdot 8^{* *}$ & 5.0 \\
\hline+5 & 363 & 386 & 18 & 665 & 643 & 21 & $21 \cdot 3$ & $40 \cdot 7^{*}$ & $6 \cdot 5$ \\
\hline+8 & 378 & 419 & 21 & 644 & 645 & 24 & $26 \cdot 2$ & $45 \cdot 1$ & $8 \cdot 8$ \\
\hline+11 & 388 & 437 & 22 & 662 & 659 & 29 & $22 \cdot 8$ & 37.0 & 8.7 \\
\hline Pair wt $\S$ & 420 & & 22 & 666 & & 26 & $33 \cdot 3$ & & 8.8 \\
\hline \multicolumn{10}{|c|}{ Expt B } \\
\hline & & & SED $\ddagger$ & & & SED $\ddagger$ & & & SED: \\
\hline-8 & 308 & 310 & 8 & 675 & 685 & 20 & $20 \cdot 5$ & $27 \cdot 5$ & $3 \cdot 6$ \\
\hline-5 & 329 & 329 & 13 & 675 & 676 & 22 & $20 \cdot 5$ & $26 \cdot 4$ & $3 \cdot 3$ \\
\hline-2 & 353 & 352 & 17 & 660 & 672 & 6 & $19 \cdot 3$ & $23 \cdot 2$ & $7 \cdot 2$ \\
\hline+1 & 373 & 379 & 15 & 665 & 669 & 9 & $21 \cdot 6$ & $43 \cdot 6^{*}$ & $5 \cdot 1$ \\
\hline+4 & 398 & 412 & 20 & 677 & 677 & 12 & 21.0 & $52 \cdot 1 * *$ & $4 \cdot 4$ \\
\hline+7 & 410 & 442 & 21 & 671 & 678 & 16 & $19 \cdot 6$ & $57 \cdot 0^{* *}$ & $5 \cdot 4$ \\
\hline+10 & 433 & 474 & 24 & 657 & 653 & 11 & $18 \cdot 5$ & $36 \cdot 5^{*}$ & $5 \cdot 2$ \\
\hline Pair wt $\$$ & 466 & & 22 & 664 & & 10 & $23 \cdot 5$ & * & 4.4 \\
\hline
\end{tabular}

The difference was statistically significant: ${ }^{*} P<0.05,{ }^{* *} P<0.01$.

$+5 \mathrm{df}$.

$\ddagger 4$ df.

$\S$ Results for control animals when they attained weights of treated steers at +11 weeks (Expt A) or +10 weeks (Expt B).

between individuals was again very noticeable (range $47 \cdot 2-61.8 \mathrm{mmol} / \mathrm{h}$ ) and when ILR was expressed per unit metabolic body-weight the individual differences were maintained throughout the experiment. Only at week +5 was there a significant $(P<0.05)$ difference between groups, with leucine ILR lower in the treated steers (Table 3). Leucine FOR also exhibited considerable between-animal variation but during control periods and for all untreated steers the within-animal values were similar (Fig. 2). The FOR for treated steers was significantly reduced from that for controls at weeks $+2(P<0.01)$ and $+5(P<0.05)$. The product of ILR $\times$ FOR (i.e. the amount of leucine oxidized, LO) ranged twofold between animals not implanted $(0.5-1.0 \mathrm{mmol}$ leucine/h). Although caution must be exercised in relating changes in LO, which spans a $4 \mathrm{~h}$ period on the day of infusion, to $\mathrm{N}$ retention which provides a composite value for the 4-6 d of chamber confinement, it was noticeable that those animals with the highest $\mathrm{LO}$ also consistently exhibited the highest urinary $\mathbf{N}$ elimination.

The calculated rates of leucine for protein synthesis $\left(\mathrm{ILR}_{\mathrm{syn}}\right)$ increased slightly throughout the period of study but, expressed relative to metabolic body-weight for both treated and untreated groups, exhibited a decline post-implant (Table 3). During control periods the treated animals had a higher average ILR $_{\text {syn }}$ (Tables 3 and 4) but post-implant values, adjusted by covariance analysis, showed that the treated steers had lower ILR syn $_{\text {nan }}$ than controls when expressed per $\mathrm{kg}$ metabolic body-weight (Table 3) although absolute rates were very similar (Table 4). Control animals at final weight, when they were assessed as 
Table 3. Expt A. Leucine irreversible loss rate (ILR), leucine fractional oxidation $(F O)$ and leucine available for protein synthesis $\left(I L R_{s y n}\right)$ for control steers and those implanted with $140 \mathrm{mg}$ trenbolone acetate $(T B A)+20 \mathrm{mg}$ oestradiol-17 $\beta(O E)$

(Mean values with their pooled standard errors of difference (SED).

Controls $n 3$, treated $n$ )

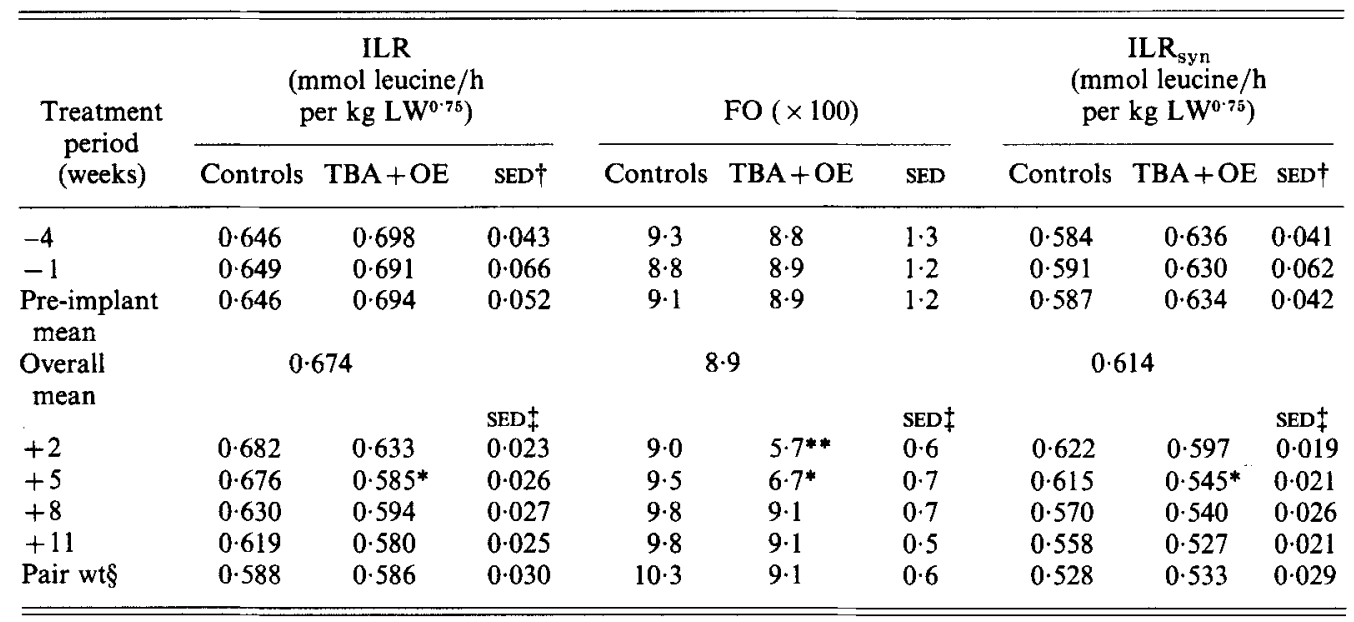

LW, live weight.

The difference was statistically significant: ${ }^{*} P<0.05,{ }^{* *} P<0.01$.

$+5 \mathrm{df}$.

$\ddagger 4 \mathrm{df}$.

$\S$ Results for control animals when they attained weights of treated steers at +11 weeks.

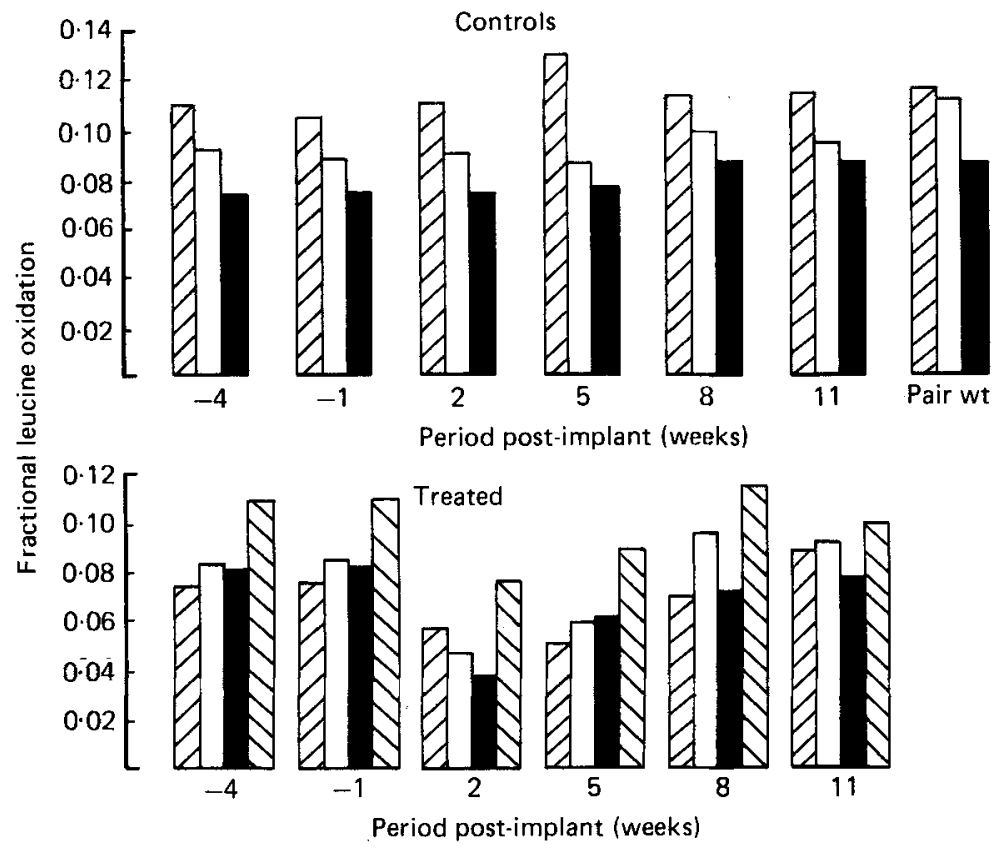

Fig. 2. Expt A. Fractional oxidation of leucine for individual animals (three control $(\llbracket, \square, \mathbf{a})$; four implanted $(\Xi, \square, \square, \nabla)$ ). For details of procedures, see p. 684 . 
Table 4. Expt A. Estimates of nitrogen flow for whole body protein synthesis (PS) and protein oxidation $(P O)$ and for the proportion of total urine $N$ elimination $(U N)$ derived from $P O$ for control steers and those implanted with $140 \mathrm{mg}$ trenbolone acetate $(T B A)+20 \mathrm{mg}$ oestradiol-17 $\beta(O E)$

(Mean values with their pooled standard errors of difference (SED).

Controls $n 3$, treated $n$ 4)

\begin{tabular}{|c|c|c|c|c|c|c|c|c|c|}
\hline \multirow{2}{*}{$\begin{array}{l}\text { Treatment } \\
\text { period } \\
\text { (weeks) }\end{array}$} & \multicolumn{3}{|c|}{$P S \dagger(g N / d)$} & \multicolumn{3}{|c|}{$\operatorname{POS}(g N / d)$} & \multicolumn{3}{|c|}{ PO: total UN } \\
\hline & Controls & $\mathrm{TBA}+\mathrm{OE}$ & SED + & Controls & $\mathrm{TBA}+\mathrm{OE}$ & SED $\ddagger$ & Controls & $\mathrm{TBA}+\mathrm{OE}$ & SED $\ddagger$ \\
\hline-4 & 362 & 398 & 24 & 36.8 & 38.6 & $5 \cdot 2$ & 0.40 & 0.45 & 0.04 \\
\hline-1 & 381 & 406 & 32 & 36.8 & $39 \cdot 5$ & $5 \cdot 4$ & 0.42 & 0.47 & 0.04 \\
\hline $\begin{array}{l}\text { Pre-implant } \\
\text { mean }\end{array}$ & 372 & 402 & 27 & $36 \cdot 8$ & $39 \cdot 1$ & $5 \cdot 3$ & 0.41 & 0.46 & 0.04 \\
\hline \multirow{2}{*}{$\begin{array}{l}\text { Overall } \\
\text { mean }\end{array}$} & \multirow{2}{*}{\multicolumn{2}{|c|}{389}} & \multicolumn{4}{|c|}{$38 \cdot 1$} & \multirow{2}{*}{\multicolumn{2}{|c|}{0.44}} & \\
\hline & & & SED $\|$ & & & SED\# & & & SED $\|$ \\
\hline+2 & 409 & 409 & 11 & 39.8 & $24 \cdot 2^{* *}$ & $3 \cdot 3$ & 0.51 & 0.23 & 0.03 \\
\hline+5 & 422 & 389 & 20 & $43 \cdot 2$ & $27 \cdot 6^{*}$ & $3 \cdot 5$ & 0.53 & 0.28 & $0 \cdot 06$ \\
\hline+8 & 400 & 412 & 16 & $43 \cdot 9$ & $40 \cdot 4$ & 3.9 & 0.48 & 0.38 & 0.05 \\
\hline+11 & 399 & 417 & 17 & 43.4 & $41 \cdot 4$ & $3 \cdot 1$ & 0.41 & 0.37 & 0.04 \\
\hline Pair wt & 400 & 422 & 26 & $46 \cdot 3$ & $41 \cdot 5$ & $2 \cdot 6$ & 0.41 & 0.38 & 0.03 \\
\hline
\end{tabular}

The difference was significantly different: ${ }^{*} P<0.05,{ }^{* *} P<0.01$.

$\dagger$ Calculated from $\operatorname{ILR}_{\text {syn }}(\mathrm{mmol} / \mathrm{h}) \times 8 \cdot 24$ (see p. 684).

$\ddagger 5 \mathrm{df}$.

$\S$ Calculated from ILR $(\mathrm{mmol} / \mathrm{h}) \times$ fractional oxidation $(\mathrm{FO}) \times 8.24$ (see p. 684).

I $4 \mathrm{df}$.

T Results for control animals when they attained weights of treated steers at +11 weeks.

fatter than treated animals, had slightly lower values for ILR $_{\text {syn }}$ and slightly higher FOR (Table 3).

$N^{\top}$-Methylhistidine elimination in the urine of steers during both experiments is shown in Fig. 3. No clear pattern was observed for Expt A where on occasions difficulties with urine collection were encountered. No such problems were observed for Expt B and treated steers showed a reduced elimination of $N^{\top}$-methylhistidine compared with control animals. For weeks +4 and +7 this decline attained statistical significance $(P<0.05)$.

\section{Effect of re-implantation (Expt A only)}

The treated steers which were re-implanted at week 13 showed small but non-significant improvements in LWG over the controls measured from a similar initial live weight (Table 1). Due to the size of the animals, collection of urine did not always attain the standards required for $\mathrm{N}$ balance studies and in consequence no $\mathrm{N}$ retention values are presented. Leucine fractional oxidation however remained similar between groups although there was a trend towards increased oxidation in the control animals at the end of the trial (Table 5). This probably reflects the accelerated fattening of the animals at this time with the increased conversion of nutrients to lipid rather than protein, and certainly the control animals at slaughter were visually very much fatter than the treated group. Indeed the control animals also showed at this time a lower heat production compared with the treated group although ILR $_{\mathrm{syn}}$ remained similar between the groups (Table 5). 


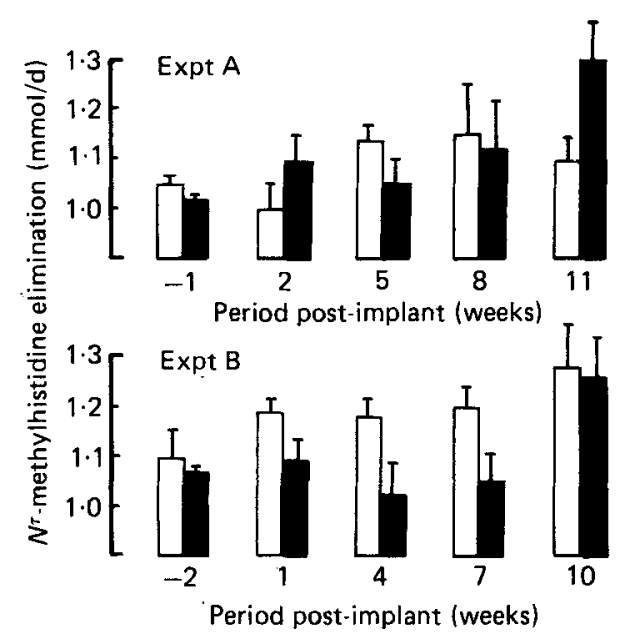

Fig. 3. Expts A and B. Mean $N^{\gamma}$-methylhistidine urinary elimination (mmol/d) for control $(\square)$ and treated ( $\square$ ) animals (from Harris et al. 1984). Values are means with their standard errors represented by vertical bars.

\section{DISCUSSION}

The experimental design adopted was intended to minimize as far as possible any effect of the steroid treatment on appetite and thus allow an examination of direct changes in energy and protein metabolism uncomplicated by alterations in intake. Most anabolic preparations enhance voluntary feed intake (see for example Sinnett-Smith et al. 1983a) although it is not known whether this is a direct response per se or a facet of the increased growth drive. Despite the restricted intake in the present experiment there was still a large increase in growth rate and $\mathrm{N}$ retention; these were not achieved by changes in digestibility or metabolizability of the diet.

Improvements in $\mathrm{N}$ retention based on changes in tissue metabolism rather than intake must be accompanied by a decrease in the catabolism of amino acids and an alteration in the rate of protein synthesis or protein degradation or both. While the efficiency of utilization of available amino acids was not measured directly in this experiment, an indirect estimate can be made based on the values for digestion and leucine metabolism. Thus, mean digestible crude protein- $\mathrm{N}$ was $125 \mathrm{~g} / \mathrm{d}$ for both control and implanted steers while for the former mean urinary $\mathrm{N}$ elimination was $100 \mathrm{~g} / \mathrm{d}$ and for the latter $85 \mathrm{~g} / \mathrm{d}$. The urinary $\mathrm{N}$ will be comprised from three main sources: (1) urea and ammonia from catabolism of tissue protein/amino acids, (2) urea and ammonia from rumen and caecal fermentation and (3) non-urea and non-ammonia components of both microbial and host animal origin. In young growing pigs where the bulk of urinary- $\mathrm{N}$ will be derived from tissue protein/amino acid oxidation: urinary- $\mathrm{N}$ values of 0.45 for control steers and 0.33 for treated animals (Table 4), the contribution of sources (2) and (3) to total urinary $-\mathrm{N}$ would be $55-57 \mathrm{~g} \mathrm{~N} / \mathrm{d}$. Thus LO values predicted tissue protein oxidation equally well then, based on mean protein oxidation: urinary- $\mathrm{N}$ values of 0.45 for control steers and 0.33 for treated animals (Table 4), the contribution of sources (2) and (3) to total urinary-N would be $55-57 \mathrm{~g} \mathrm{~N} / \mathrm{d}$. Thus $\mathrm{N}$ available for protein anabolism was probably only $70 \mathrm{~g}$ (i.e. $125-55 \mathrm{~g}$ ) which compares with a value of $55 \mathrm{~g} \mathrm{~N}$ estimated as described in Section 4.10 of The Nutrient Requirements of Ruminant Livestock (Agricultural Research Council, 1980) so that the efficiency of deposition altered from approximately 0.36 in control steers to 0.57 in the treated animals. These values are low compared with an efficiency of utilization of 0.75 as suggested by the 


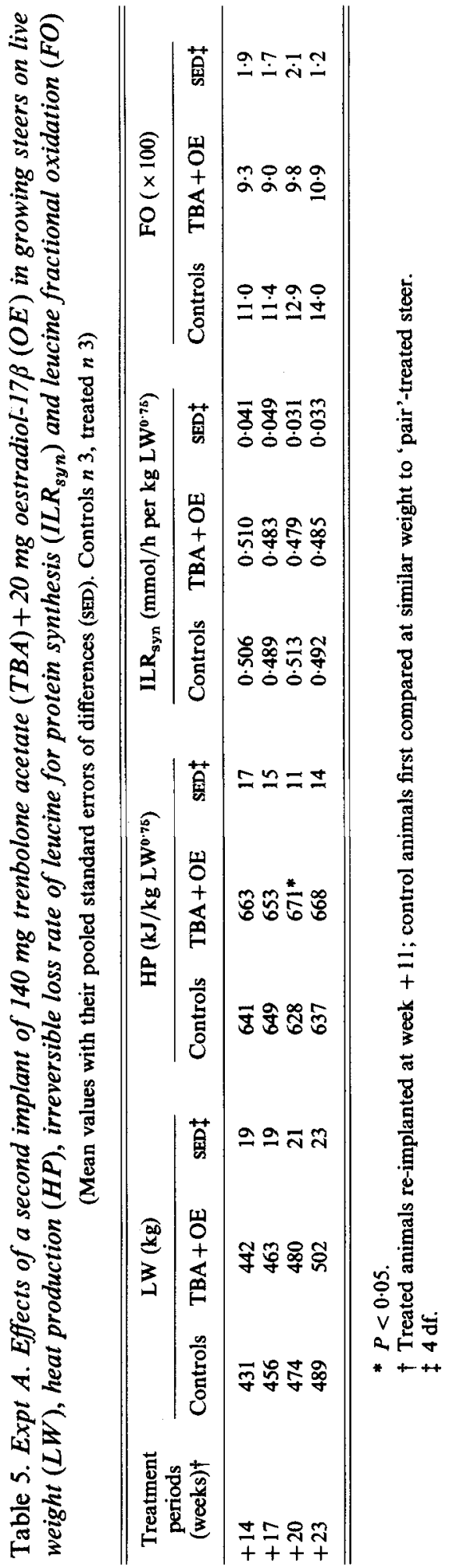


Agricultural Research Council (1980), a value derived from studies on young calves, but are compatible with efficiencies of 0.24-0.59 observed with lambs or mature sheep fed on forage diets (MacRae et al. 1972; MacRae \& Ulyatt, 1974).

Such is the rate of protein turnover in cattle that although the control steers showed protein deposition at approximately $125 \mathrm{~g} / \mathrm{d}$ the minimum rate of protein synthesis was between 2.2 and $2.5 \mathrm{~kg} / \mathrm{d}$. The ratio, deposition:synthesis for the untreated animals was thus only 0.05 at most. If the increased retention of $125 \mathrm{~g} / \mathrm{d}$ protein observed for treated steers was accomplished through increased synthesis then, provided this could be deposited at maximal efficiency, ILR $_{\text {syn }}$ need only have risen by 0.05 . The practical sensitivity for detection of differences in ILR approaches 0.05 so under these circumstances effects on the synthetic process would be difficult to detect. High efficiencies for retention of incremental amounts of synthesized protein have, however, not been reported. In experiments where protein synthesis has been altered by variation in intake the ratio, deposition: synthesis has been low: 0.46 for growing pigs receiving amounts between maintenance (M) and $3 \mathrm{M}$ (Reeds et al. 1980) and 0.41 for finishing beef steers offered from $1.6 \mathrm{M}$ to zero intake (G. E. Lobley, unpublished results). While comparison of the present steroid treatment with nutritional studies is not necessarily valid it does suggest that if similar conditions existed, increases of $0 \cdot 10-0 \cdot 15$ in ILR $_{\mathrm{syn}}$ would be expected. These clearly were not realized and indeed the $\operatorname{ILR}_{\text {syn }}$ for treated animals declined from that observed pretreatment (Table 3).

In other experiments in which the effects of steroids have been examined, food intake has often not been controlled so direct comparisons with the present study are difficult. For example, in ewe lambs treated with TBA, Sinnett-Smith et al. (1983a) observed an increase in leucine ILR of 0.27 above that of control animals but the treated group ate considerably more (average 1.81 v. $1.30 \mathrm{~kg} / \mathrm{d}$ ). Similar differences in food intake were apparent for female rats and lambs as a result of TBA treatment (Vernon \& Buttery, 1976, $1978 b$; Sinnett-Smith et al. 1983a) the combined effect of the steroid and increased appetite would probably have Thus, although the fractional rate of muscle protein synthesis was decreased in both female rats and lambs as a result of TBA-treatment (Vernon \& Buttery, 1976, 1978 $b$; Sinnett-Smith et al. $1983 a$ ) the combined effect of the steroid and increased appetite would have probably caused an increase in muscle mass. In consequence total muscle protein synthesis would be similar between control and treated animals. The ILR procedure used in this study permits repeated observations on the same animal in a non-destructive manner but describes only the effect on whole-body leucine metabolism. If the action of certain anabolic steroids are directed against individual targets, such as skeletal muscle as suggested by the work of Buttery and colleagues (e.g. Vernon \& Buttery, 1978 a, b; Sinnett-Smith et al. 1983a), then specific effects on tissue protein metabolism may be partly masked within the whole-body pattern. While it is difficult to measure protein degradation some indication of changes in this process, for muscle at least, may be gained from values for urinary $N^{\tau}$-methylhistidine elimination. In rats TBA treatment decreased $N^{\top}$-methylhistidine elimination while the same steroid in combination with $\mathrm{OE}$ also led to a reduced elimination in both the present study and that on young growing bulls by van Eenaeme et al. (1983). Although the use of $N^{\tau}$-methylhistidine elimination as an index of muscle protein degradation in animals has been criticized in recent years (cf. Harris, 1981; Millward et al. 1983) the method may still have validity in qualitative terms. If the $N^{\top}$-methylhistidine is regarded as being derived exclusively from muscle then calculations (based on Harris \& Milne, 1981) suggest that the decrease in catabolism would yield a maximum improvement in muscle protein retention of $45 \mathrm{~g} / \mathrm{d}$, i.e. less than expected from changes in LWG, $N$ retention and LO rates.

Increased protein deposition mediated through a steroid-induced decrease in protein degradation as opposed to an increase in protein synthesis has implications for the energy 
requirement of the animal. The energy costs of protein breakdown are believed to be small whereas the synthetic process requires at least $4.5 \mathrm{~kJ} / \mathrm{g}$. Thus the increased energy requirement for protein deposition predicted by classical regression analyses (see Tess et al. 1984) is, almost certainly, related normally to the greater protein synthesis which accompanies increased intake (Reeds et al. 1980). However, increased $\mathrm{N}$ retention which results from reduced degradation rather than increased protein synthesis need not be accompanied by a rise in energy expenditure. Indeed TBA does not significantly effect energy retention when given either separately to female rabbits (Lobley et al. 1983b) or in combination with $\mathrm{OE}$ to steers (Huisman et al. 1980; present study).

Despite its use as a 'synthetic androgen', TBA appears to show marked differences in metabolic response compared with testosterone whether the hormone is derived either endogenously or exogenously. Thus, compared with steers, bulls are recognized to have a higher energy expenditure (Webster et al. 1977; Agricultural Research Council, 1980) which is partly due to maintenance of the greater proportion of lean body mass and partly to the costs of increased behavioural aggression and mobility. However, administration of TBA does not result in increased energy expenditure. Equally, while selective therapy of young female rats with testosterone leads to increases in voluntary food intake and the fractional rates of muscle protein synthesis and degradation (Martinez et al. 1984), TBA, although also stimulating appetite, causes a decrease in the fractional rates of muscle protein synthesis and degradation (Vernon \& Buttery, 1976, 1978 a, b). The action of TBA may in part, however, involve testosterone because of effects on reducing the available testosterone binding sites in the sarcosol (Sinnett-Smith et al. 1983b). Similarly, TBA and testosterone appear to act directly on the pituitary (cf. Schanbacher, 1982; Gettys et al. 1984) although whether this is through the same receptor is not known. Whether these common effects can explain the action of TBA is, however, unclear.

These descriptions of the actions of TBA may not be totally applicable to the present study as the information is derived from experiments where TBA was administered alone whereas here it was given in association with OE. The effects of the TBA and OE together are at least additive in terms of production response (see Galbraith \& Topps, 1981) but whether their metabolic effects are dependent or independent when in combination is not clear. In the present study the OE was included to achieve the maximum response and magnify metabolic changes. The net effect was to achieve an extra LWG of $35 \mathrm{~kg}$ in 10 weeks. This value approaches the $50 \mathrm{~kg}$ which separated bulls from steers after 32 weeks of monitoring in the experiments of Webster et al. (1977). Hence it appears that a considerable recovery of the normal growth penalty associated with castration can be achieved. The steroid combination is in practice very effective, at least with the first dose of the drug, but the precise mechanisms whereby the changes in protein metabolism are achieved remain uncertain.

The authors wish to record their grateful thanks to the following: Mr J. Gunn and Mr K. Rae for assistance with the catheterization procedure; $\mathrm{Mr} \mathrm{P}$. Dewey and his staff for analysis of feed and excreta; and to Hoechst Ltd for the gift of Revalor.

\section{REFERENCES}

Agricultural Research Council (1980). The Nutrient Requirements of Ruminant Livestock. Slough: Commonwealth Agricultural Bureaux.

Association of Official Agricultural Chemists (1980). Official Methods of Analysis, 13th ed. Washington, DC: Association of Official Agricultural Chemists.

Blaxter, K. L., Brockway, J. M. \& Boyne, A. W. (1972). Quarterly Journal of Experimental Physiology 57, 60-72. Brockway, J. M. (1979). Laboratory Practice 28, 139. 
Brouwer, E. (1965). In Energy Metabolism, pp. 441-443 [K. L. Blaxter, editor]. New York and London: Academic Press.

Donaldson, I. A., Hart, I. C. \& Heitzman, R. J. (1981). Research in Veterinary Science 30, 7-13.

Galbraith, H. \& Topps, J. H. (1981). Nutrition Abstracts and Reviews Series B 51, 521-540.

Gettys, T. W., D'Occhio, M. J., Henricks, D. M. \& Schanbacher, B. D. (1984). Journal of Endocrinology 100, $107-112$.

Grovum, W. L. \& Williams, V. J. (1973). British Journal of Nutrition 30, 313-329.

Harris, C. I. (1981). Biochemical Journal 194, 1011-1014.

Harris, C. I. \& Milne, G. (1981). British Journal of Nutrition 45, 411-422.

Harris, C. I., Milne, G., McDiarmid, R. M. \& Brewer, A. C. (1984). Proceedings of the Nutrition Society 43, 5A.

Heitzman, R. J. (1980). In Protein Deposition in Animals, pp. 193-203. [P. J. Buttery and D. B. Lindsay, editors]. London: Butterworths.

Huisman, J., van Weerden, E. J., Berende, P. L. M. \& van der Wal, P. (1980). Journal of Animal Science 51, Suppl. $1,287$.

Lobley, G. E., Connell, A., Harris, C. I., Milne, G. \& McDiarmid, R. (1983a). In IVth International Symposium on Protein Metabolism and Nutrition, vol. 2, pp. 69-72 [R. Pion, M. Arnal and D. Bonin, editors]. Clermont-Ferrand: INRA.

Lobley, G. E., Connell, A. \& Watson, B. (1985). International Journal of Applied Radiation and Isotopes (In the Press).

Lobley, G. E., Milne, V., Lovie, J. M., Reeds, P. J. \& Pennie, K. (1980). British Journal of Nutrition 43, $491-502$.

Lobley, G. E., Smith, J. S., Mollison, G., Connell, A. \& Galbraith, H. (1982). Proceedings of the Nutrition Society 41, 28 A.

Lobley, G. E., Walker, A. \& Connell, A. (1983b). Animal Production 36, 111-115.

MacRae, J. C. \& Ulyatt, M. J. (1974). Journal of Agricultural Science, Cambridge 82, 309-319.

MacRae, J. C., Ulyatt, M. J., Pearce, P. D. \& Hendtlass, J. (1972). British Journal of Nutrition 27, $39-50$.

Martinez, J. A., Buttery, P. J. \& Pearson, J. T. (1984). British Journal of Nutrition 52, 515-521.

Millward, D. J., Bates, P. C., de Benoist, B., Brown, J. G., Cox, M., Halliday, D., Odedra, B. \& Rennie, M. J. (1983). In IVth International Symposium on Protein Metabolism and Nutrition, vol. 1, pp. 69-96 [R. Pion, M. Arnal and D. Bonin, editors]. Clermont-Ferrand: INRA.

Reeds, P. J., Cadenhead, A., Fuller, M. F., Lobley, G. E. \& McDonald, J. D. (1980). British Journal of Nutrition 43, 445-455.

Schanbacher, B. D. (1982). Journal of Animal Science 51, 679-684.

Sinnett-Smith, P. A., Dumelow, N. W. \& Buttery, P. J. (1983a). British Journal of Nutrition 50, $225-234$.

Sinnett-Smith, P. A., Palmer, C. A. \& Buttery, P. J. (1983b). In IVth International Symposium on Protein Metabolism and Nutrition, vol. 2, pp. 77-80 [R. Pion, M. Arnal and D. Bonin, editors]. Clermont-Ferrand: INRA.

Tan, T. N., Weston, R. H. \& Hogan, J. P. (1971). International Journal of Applied Radiation and Isotopes 22, 301-308.

Tess, M. W., Dickerson, G. E., Nienaber, J. A., Yen, J. T. \& Ferrell, C. L. (1984). Journal of Animal Science 58, 111-122.

van Eenaeme, C., Baldwin, P., Lambot, O. \& Bienfait, J. M. (1983). In IVth International Symposium on Protein Metabolism and Nutrition, vol. 2, pp. 81-84 [R. Pion, M. Arnal and D. Bonin, editors]. Clermont-Ferrand: INRA.

Varley, M. A., Atkinson, T. \& Ross, L. N. (1981). Theriogenology 16, 179-184.

Vernon, B. G. \& Buttery, P. J. (1976). British Journal of Nutrition 36, 575-579.

Vernon, B. G. \& Buttery, P. J. (1978a). Animal Production 26, 1-9.

Vernon, B. G. \& Buttery, P. J. (1978 b). British Journal of Nutrition 40, 563-572.

Wainman, F. W., Dewey, P. J. S. \& Brewer, A. C. (1984). Feedingstuffs Evaluation Unit, Fourth Report 1984. Aberdeen: Rowett Research Institute.

Wainman, F. W., Smith, J. S. \& Dewey, P. J. S. (1975). Journal of Agricultural Science, Cambridge 84, $109-111$.

Webster, A. J. F., Smith, J. S. \& Mollison, G. S. (1977). Animal Production 24, 237-244. 